Accountability is meaningful only to the extent that tertiary education institutions are actually empowered to operate in an autonomous and responsible way. In the final analysis, their successful evolution will hinge on finding an appropriate balance between credible accountability practices and favorable autonomy conditions.

Author's note: The findings, interpretations, and conclusions expressed in this article are entirely those of the author and should not be attributed in any manner to the World Bank, the members of its Board of Executive Directors, or the countries they represent.

\section{Internationalization: A Decade of Changes and Challenges}

\section{JANE KNIGHT}

Jane Knight is adjunct professor in the Comparative, International Development Education Centre, Ontario Institute for Studies in Education, University of Toronto, Canada. E-mail: janeknight@sympatico.ca.

A $\mathrm{s}$ we progress into the 2ist century, the international dimension is a key factor shaping and challenging the higher education sector in countries all over the world. During the last decade internationalization has increased in importance, impact, and complexity. It is a formidable force of change in its role as agent and reactor to the realities of globalization. But are all these changes positive?

\section{New Actors}

For several decades international academic relations have generally been under the purview of ministries of education, culture, and foreign affairs. Since the mid-I990s, ministries of immigration, trade, employment, industry, and especially science and technology have focused on the international recruitment of students and professors; the global competitiveness for the production and commodification of knowledge; and the commercial and economic benefits of cross-border education. Not only have additional national government agencies become more engaged, so have intergovernmental bodies such as UNESCO, and the Organization for Economic Cooperation and Development, and the World Bank, as well as international and regional nongovernmental agencies. In fact, international education is now seen by both politicians and academic leaders as instrumental to regionalization initiatives such as those underway in Europe through the Bologna process, in Africa through the African Union higher education harmonization project, and the efforts in Latin America to work toward a community of higher education. The role of higher education as an international or regional political actor has clearly gained ground in the last decade.

\section{Increased Demand and a Diversity of Providers}

The forecasted growth for international education moves from I. 8 million in 2000 to about 7 million in 2025 . This has major implications for the number and type of institutions, companies, organizations, and networks involved in the cross-border provision of higher education. Traditional public and private universities, primarily in Europe, North America, and Asia, are more and more active in sending and receiving education programs through a variety of delivery modes including franchising, branch campuses, twinning, and distance. At the same time, alternative or nontraditional providers are seeking business opportunities based on the rising demand for higher education and the attractiveness of foreign degrees for employment mobility. As a result, more than 50 large transnational companies are publicly traded on stock exchanges and are active in providing international educational programs, degrees, and services on a for-profit basis. In addition, multitudes of small private companies are now involved in crossborder education. Many offer quality education programs and recognized qualifications, but others are rogue, temporary, and unaccredited profit makers. The "for-profit" side of internationalization is increasing in many countries of the world, but certainly not all.

The recent inclusion of education services in the General Agreement for Trade in Services has been a wake-up call for higher education. As already noted, the export and import of higher education programs have been steadily growing, and so it should be no surprise that the World Trade Organization sees the education sector as a lucrative market. But what is unexpected, and of concern to many, is that the movement of private higher education services and programs between coun-

International education is now seen by both politicians and academic leaders as instrumental to regionalization initiatives such as those underway in Europe through the Bologna process.

tries is now subject to multilateral trade regulations where before it was done primarily on a bilateral basis, usually between government departments related to education and foreign affairs-certainly not trade. This raises new implications, questions, and challenges for higher education.

\section{QUALITY}

A worrisome trend is the treatment of quality assurance and accreditation as strategies for "international branding" and market position rather than for academic improvement pur- 
poses. The international ranking "game" is another illustration of a preoccupation with international standings based on questionable and biased indicators. To what end does this competitiveness for international status serve? Is it to improve higher education's contribution to solving some of the global challenges? Or is it a sign of the market approach, where often position is more important than substance? Internationalization can be used as a strategy to enhance the international, global, and intercultural dimensions of teaching and learning, research and knowledge production, and service to society. It also has the potential to improve quality, but a preoccupation with status plus the emergence of rogue providers, diploma, and accreditation mills are overshadowing and jeopardizing the added value that internationalization can bring to higher education.

More than 50 large transnational companies are publicly traded on stock exchanges and are active in providing international educational programs, degrees, and services on a for-profit basis.

\section{Institutional Policies and Activities}

More institutions around the world are establishing a central office and an institutionwide policy for internationalization. This trend takes many forms but illustrates a gradual change from a reactive ad hoc approach to internationalization to a more proactive planned approach. Nevertheless, a strategic approach is still out of reach for most institutions. Considerations as to the obstacles with regard to internationalizing an institution have evolved. Previously, the key barriers were viewed as lack of senior-level commitment, finances, and policies. Currently, the major obstacles include lack of expertise in the international office and lack of faculty interest, involvement, and international/intercultural experience. Clearly, human resources are now a major challenge and in need of more attention.

The approach of a long list of inactive bilateral agreements has been shifted to participating in international or regional networks. In fact, networks are becoming important branding tools as institutions look for prestigious partners and funding sources. Networks are often formed to enhance student and professor exchanges, develop joint curriculum and degrees, undertake benchmarking exercises, or engage in collaborative research. In other cases, networks are oriented to cooperating for competitive purposes with regard to student recruitment, franchising programs, or applying for research grants. It is interesting to note that the recent worldwide survey by the International Association of Universities found that the three most important growth areas for internationalization include institutional agreements and networks as number one, fol- lowed by outgoing student mobility and international research collaboration.

International student recruitment remains a top priority for traditional receiving countries like the United States, United Kingdom, Australia, and Canada; but new initiatives by several European and Asian countries are making them popular destination points. The efforts of Asian countries and several wealthy Gulf states are worth watching in the next few years as they compete for increased market share of international students.

\section{Rationales, Benefits, ANd Risks}

Many observers would claim that in the last decade they have witnessed a dramatic movement of internationalization rationales toward income production. While this trend may be true for a small group of countries, it is certainly not the case for the majority of institutions around the world. A more accurate description is an increased diversification of rationales driving internationalization at institutional and national levels. Current leading motivations still focus on enhancing the international knowledge and intercultural skills of students and professors, but other goals include the creation of an international profile or brand, improving quality, increasing national competitiveness, strengthening research capacity, developing human resources, and diversifying the source of faculty and students. In the past decade the importance and benefits of internationalization have been recognized, but at the same time, new risks have been widely acknowledged. The most important risks include commercialization, foreign degree mills, brain drain, and growing elitism.

All in all, we have seen a very dynamic evolution of internationalization in the past Io years. It is critical that we continue to nurture positive results and remain vigilant to potentially negative and unexpected implications so that internationalization builds on strengthening individual, institutional, community, and national development in the more interdependent and interconnected world in which we live.

\section{Private Higher Education: Patterns and Trends}

\section{Daniel C. Levy}

Daniel C. Levy is Distinguished Professor at the University at Albany, State University of New York, and director of the Program for Research on Private Higher Education. E-mail: DLevy@uamail.albany.edu.

Tn its I2 years, International Higher Education has published 1 many articles on the continued growth of higher education, 